\title{
Characterization of Phytophthora capsici from Michigan Surface Irrigation Water
}

\author{
A. J. Gevens, R. S. Donahoo, K. H. Lamour, and M. K. Hausbeck
}

First author: Department of Plant Pathology, Michigan State University, East Lansing 48824; second author: Department of Entomology and Plant Pathology, University of Tennessee, Knoxville 37996; third author: Department of Entomology and Plant Pathology, University of Tennessee, Knoxville 37996; and fourth author: Department of Plant Pathology, Michigan State University, East Lansing 48824. Accepted for publication 29 September 2006.

\begin{abstract}
Gevens, A. J., Donahoo, R. S., Lamour, K. H., and Hausbeck, M. K. 2007. Characterization of Phytophthora capsici from Michigan surface irrigation water. Phytopathology 97:421-428.

Phytophthora capsici infects cucurbitaceous and solanaceous crops worldwide. In free water, $P$. capsici sporangia release zoospores that may be disseminated by moving surface water. Surface irrigation sources (river system, ponds, and ditches) in three Michigan counties with a history of $P$. capsici-susceptible crop production were monitored for the pathogen during four growing seasons (2002 to 2005). Pear and cucumber baits were suspended in water at monitoring sites for 3- to 7-day intervals and water temperature was recorded. Baits were washed and

$(N=270)$ were screened for sensitivity to the fungicide mefenoxam and characterized for mating type (MT). P. capsici isolates resistant to mefenoxam were common in water sources from southwest and southeast Michigan. Most monitoring sites yielded isolates of a 1:1 ratio of A1:A2 MTs. Amplified fragment length polymorphism analysis of select isolates from 2002 to 2004 indicated a lack of similarity groups persisting over time and in specific geographical locations. Data suggest that $P$. capsici did not overwinter in any of the surface water sources monitored. Water temperatures were correlated to positive $P$. capsici detection from all monitoring sites. The frequent detection of $P$. capsici in surface water used for irrigation in the primary vegetable growing regions in Michigan suggests that this is an important means of pathogen dissemination.
\end{abstract} lesions were excised and cultured on water agar amended with rifampicin and ampicillin. $P$. capsici was detected at monitoring sites in multiple years, even when non-host crops were planted nearby. Recovered isolates
Additional keywords: crown and root rot, pathogen survival, irrigation water, soilborne disease, water infestation.
The fungal-like oomycete Phytophthora capsici (Leonian) infects solanaceous and cucurbitaceous hosts including cucumber, eggplant, tomato, pepper, pumpkin, squash, melon, and zucchini $(5,7,8,14,16)$. Recently, lima and snap beans have been added to this list of susceptible crops $(6,11)$. In addition to crown rot and foliar wilting, $P$. capsici causes fruit rot symptoms which appear as water-soaked lesions that expand rapidly. Sporangia and/or oospores develop in the lesions resulting in fruit surfaces with a powdered-sugar appearance. Infected fruit quickly break down both in the field and postharvest (14). Foliar blighting on cucurbit and solanaceous crops is not typically seen in Michigan (14).

Oospores overwinter in soil and plant debris and initiate primary plant infections in the spring $(7,8,20,21,23)$. Oospores are produced when mycelium of A1 and A2 mating types (MTs) come into contact $(7,8,16,18,33,44)$. Both MTs have been documented in naturally infested fields in Michigan (20-22) and other states (14). Mycelia and sporangia develop on infected host tissue under warm $\left(25\right.$ to $\left.28^{\circ} \mathrm{C}\right)$, wet conditions $(1,3,7,8,14,38,43)$. Sporangia and zoospores are secondary asexual inoculum produced during the growing season, which cause rapid progression of disease $(7,8)$. In free water, lemon-shaped sporangia release 20 to 40 motile zoospores, each capable of causing infection $(1,3,7,8,14)$.

$P$. capsici management requires a multifaceted approach of both cultural and chemical strategies. Establishing P. capsicisusceptible crops in well-drained fields, on raised plant beds, and avoiding the planting of low-lying sections of fields help to

Corresponding author: M. K. Hausbeck; E-mail address: hausbec1@msu.edu

doi:10.1094/PHYTO-97-4-0421

(C) 2007 The American Phytopathological Society manage disease. Conservative irrigation, especially close to harvest is recommended $(14,36)$. When applied preventively and frequently, fungicides can also limit disease (14). However, resistance of $P$. capsici to the once commonly used fungicide mefenoxam has been widely documented in Michigan and other vegetable production regions $(2,14,22,25-28,30,40-42,47)$. Because current measures, even when used in a comprehensive program, have not been adequate, preventing the introduction of $P$. capsici into new agricultural sites is critical (14).

Oomycetes have been identified in surface water used in various commercial plant production systems $(4,15,24,32,34,49)$. Phytophthora and Pythium spp. have been detected in recycled water used for irrigation in greenhouse and nursery production in Virginia $(4,15)$. P. cactorum was identified in surface water used for irrigation of pear in the state of Washington (49). Both $P$. cinnamomi and $P$. megasperma were detected in surface water used in a cranberry production system in New Jersey (34). In North Carolina (24) and California (32), P. parasitica was detected in furrow irrigation water which moved the pathogen from loci of infestation to parts of the field that were uninfested. In 2001, P. capsici was recovered from irrigation ponds on two farms in Michigan (14). Additional irrigation water sources were monitored for P. capsici in 2002 and 2003 and the pathogen was frequently detected in a river, creek, and a naturally fed pond (10). In 2005, P. capsici was also documented in Florida tailwater (surface run-off water) using water filtration and lemon leaf baiting techniques (37).

Since many Michigan vegetable growers rely on surface water for irrigation of susceptible crops, our primary objective was to recover $P$. capsici from surface irrigation water and to determine the prevalence and frequency of the pathogen in water used for irrigation (river system, ponds, and ditches). In addition, water 
temperature and rainfall were monitored and analyzed for correlation to $P$. capsici incidence and the diversity of the isolates was characterized using mating type, sensitivity to mefenoxam, and genetic fingerprinting. Preliminary reports from this research have been published (10).

\section{MATERIALS AND METHODS}

Site selection. Water monitoring sites were either adjacent to a vegetable production field with a history of $P$. capsici infestation or adjacent to a field with a crop infected with $P$. capsici during the 2002 to 2005 growing seasons. Sites were selected in three of the primary vegetable production regions of Michigan: northwest (NW; Oceana County), southwest (SW; Allegan County), and southeast (SE; Lenawee County). Water source types included ponds fed by deep wells, naturally fed ponds, river sites, a creek, and ditches. Baiting was usually initiated in the spring (April or May) and terminated at the end of the growing season (October) (Table 1).

Baiting, $P$. capsici identification, water temperature, and rainfall. Baiting traps were constructed by attaching four segments of 2.5-in.-diameter polyethylene foam cylinders to the tops of plastic milk crates with a securable lid (Fig. 1A). Each trap contained two green pears, purchased from a local supplier, and a cucumber fruit produced at the Michigan State University Plant Pathology Farm, a site without a history of $P$. capsici. Pears were selected as baits for $P$. capsici because they had been documented to serve as adequate bait for other Phytophthora spp. from soil $(7,29,31)$. In our initial laboratory tests, pears were suitable baits for $P$. capsici in water (data not shown). Similarly, Yamak et al. (49) found pears to be susceptible to Phytophthora spp. when used in a water system. A WatchDog data logger temperature sensor from Spectrum Technologies, Inc. (Plainfield, IL) was attached to the milk crate to measure and record water temperature each hour (Fig. 1A). Each trap was secured to a fixed point and deployed into one of the following water sources: river, creek, pond, or ditch (Fig. 1B). Baits and temperature sensors were replaced once or twice weekly. Hereafter, a baiting period refers to the time that the baits remained in the water (3- to 7-day period). After removal from the traps, cucumbers and pears (Fig. $1 \mathrm{C}$ and $\mathrm{D})$ were rinsed in distilled, de-ionized water, dried under ambient laboratory conditions, and tissue from lesion margins was placed onto water agar amended with rifampicin $(30 \mathrm{ppm})$ and ampicillin (100 ppm). After 3 to 5 days of incubation under constant fluorescent lighting at 23 to $25^{\circ} \mathrm{C}$, plates were observed with a compound microscope and $P$. capsici was identified based on morphological characteristics according to the Phytophthora spp. key by Waterhouse (48). Isolates positively identified on amended water agar (31) were transferred to BARP (25 ppm of benomyl, $100 \mathrm{ppm}$ of ampicillin, $30 \mathrm{ppm}$ of rifampicin, and $100 \mathrm{ppm}$ of pentachloronitrobenzene)-amended UCV8 (840 ml of distilled water, $163 \mathrm{ml}$ of unclarified V8 juice, $3 \mathrm{~g}$ of $\mathrm{CaCO} 3$, and $16 \mathrm{~g}$ of Bacto agar) plates (39) incubated under lab lighting at 23 to $25^{\circ} \mathrm{C}$ for 3 to 5 days. Single-zoospore isolates were obtained according to Lamour and Hausbeck (19). Single-zoospore cultures were stored on UCV8 plates at $15^{\circ} \mathrm{C}$ and transferred bimonthly. Additionally, two 7-mm agar plugs were placed in $1.5-\mathrm{ml}$ sterile microcentrifuge tubes with two sterilized hemp seeds and $1.0 \mathrm{ml}$ of sterile distilled water, incubated at 23 to $25^{\circ} \mathrm{C}$ for 2 weeks under laboratory lighting, and stored long term at $15^{\circ} \mathrm{C}(8)$. Select isolates from 2002 to 2004 were further characterized by amplified fragment length polymorphism (AFLP) analysis. Data from temperature sensors were downloaded using Spec Ware 6 data logger software (Spectrum Technologies, Inc., Plainfield, IL) and hourly data were averaged for each baiting period. Rainfall data for each baiting location were collected from nearby weather monitoring stations, totaled for each baiting period, and analyzed using nonlinear polynomial regression analysis.

TABLE 1. Time of sampling and P. capsici detection for southwest (SW) Michigan (Allegan County) river sites, northwest (NW) Michigan (Oceana County) pond and ditch sites, and one southeast (SE) Michigan (Lenawee County) ditch site, 2002 to 2005

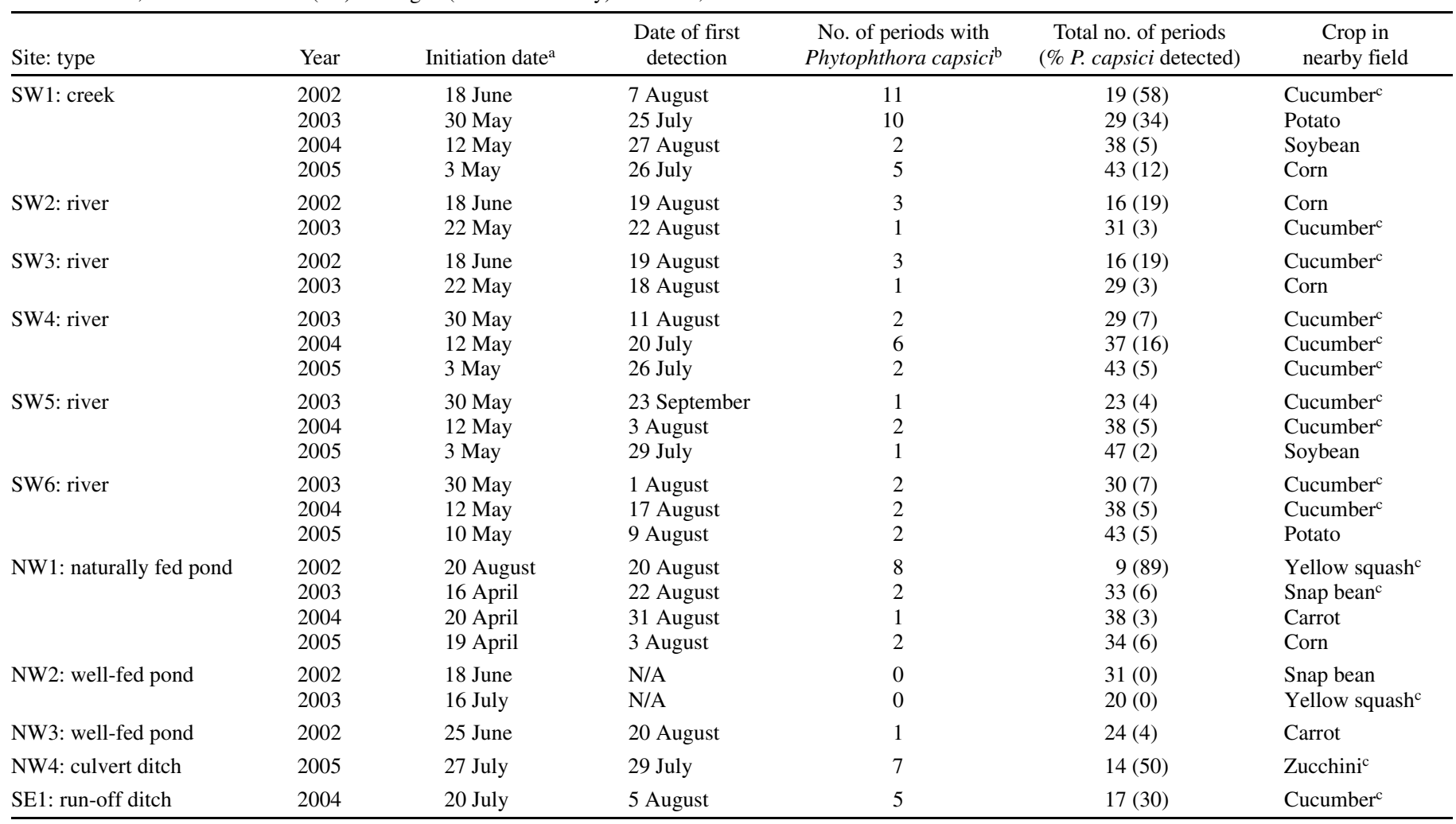

a Indicates baiting termination occurred mid-October.

${ }^{\mathrm{b}}$ Baiting period was 3 to 7 days during which baits were in surface irrigation water.

${ }^{\mathrm{c}}$ Indicates that nearby crop exhibited disease caused by $P$. capsici. 
MT determination. MTs of $P$. capsici isolates were determined by placing agar plugs (7.0-mm diameter) from the edge of 1week-old expanding single-zoospore-derived cultures onto a V8juice agar plate. At a distance of $3 \mathrm{~cm}$ from the baiting isolate plug, a 7.0-mm plug of a known A1 or A2 MT was placed. Known standard isolates of $P$. capsici were OP97 (A1 MT) isolated from pickling cucumber fruit in NW Michigan in 1997; and SP98 (A2 MT) isolated from pumpkin fruit in SW Michigan in 1998. Culture numbers refer to isolates maintained in the Phytophthora stock collection in M. Hausbeck's laboratory in the Department of Plant Pathology, Michigan State University. After 10 to 14 days incubation at 23 to $25^{\circ} \mathrm{C}$ under darkness, plates were observed at $\times 200$ magnification for the presence of oospores between the two plugs.

Mefenoxam sensitivity determination. Mefenoxam sensitivity was determined by placing a 7.0-mm agar plug from a 1-week-old single-zoospore-derived culture on one plate $(100 \times 15 \mathrm{~mm})$ of V8-juice agar and two plates $(100 \times 15 \mathrm{~mm})$ of V8-juice agar amended with 100 ppm of mefenoxam (Ridomil Gold EC, 48\% a.i. suspended in sterile distilled water and added to cooled agar). Plates were incubated at 23 to $25^{\circ} \mathrm{C}$ for 3 days, and colony diameters were measured. Growth of an isolate on amended media compared with unamended media was classified as sensitive ( $\mathrm{S}$, $<30 \%$ of the control), intermediately sensitive (I, 30 to $90 \%$ of the control), and resistant ( $\mathrm{R},>90 \%$ of the control) (12).

DNA extraction and AFLP analysis. Mycelium was grown in antibiotic-amended V8 broth. Genomic DNA was extracted from approximately $10 \mathrm{mg}$ of lyophilized mycelium using DNeasy Mini-Kits (Qiagen, Valencia, CA). DNA was quantified on an agarose gel with known standards.

AFLP reactions were conducted as described by Habera et al. (13). Pre-amplification reactions were carried out using Eco (E-0) and Mse (M-0) primers (no selective nucleotides) and selective amplifications were conducted using the primer pair E-12/M-21 (Eco primer with AC as the selective nucleotides and the Mse primer with $\mathrm{CA}$ as the selective nucleotides). The selective primers allow highly reproducible amplification of a specific subset of the adaptor-modified restriction fragments which are referred to as AFLP markers (46). Fluorescent products from the selective amplifications were analyzed on a CEQ 8000 Genetic Analysis System (Beckman Coulter, Fullerton, CA) according to the manufacturer's protocols. Monomorphic and polymorphic AFLP markers were manually scored using the CEQ 8000 software (Beckman Coulter). The markers were transformed into binary data and imported into NTsys software (Sinaur Associates, Sunderland, MA) and subjected to similarity and cluster analysis using unweighted pair-group method with arithmetic mean (UPGMA). The resulting genetic similarity tree from this data is presented in Figure 2.

\section{RESULTS}

P. capsici detection. River system. Six sites along a SW Michigan (Allegan County) river system (Fig. 3) in a region with a 40-year history of cucumber production yielded $211 \mathrm{P}$. capsici isolates during a 4-year period. The pathogen was detected at each site for multiple years even when a $P$. capsici host crop was absent in nearby fields. While baiting was initiated in the spring and early summer (prior to 18 June), P. capsici was not detected prior to 20 July during the course of this study. In SW1 (Fig. 3), 11 baiting periods (from 7 August to 1 October) during 2002 yielded $P$. capsici. Detection of the pathogen occurred in each of three additional growing seasons (2003 to 2005) despite a nearby crop rotation of potato, soybean, and corn (Table 1). Due to the high number of baiting periods (10) with positive $P$. capsici identification at SW1 site during 2003, 10 potato plants in the
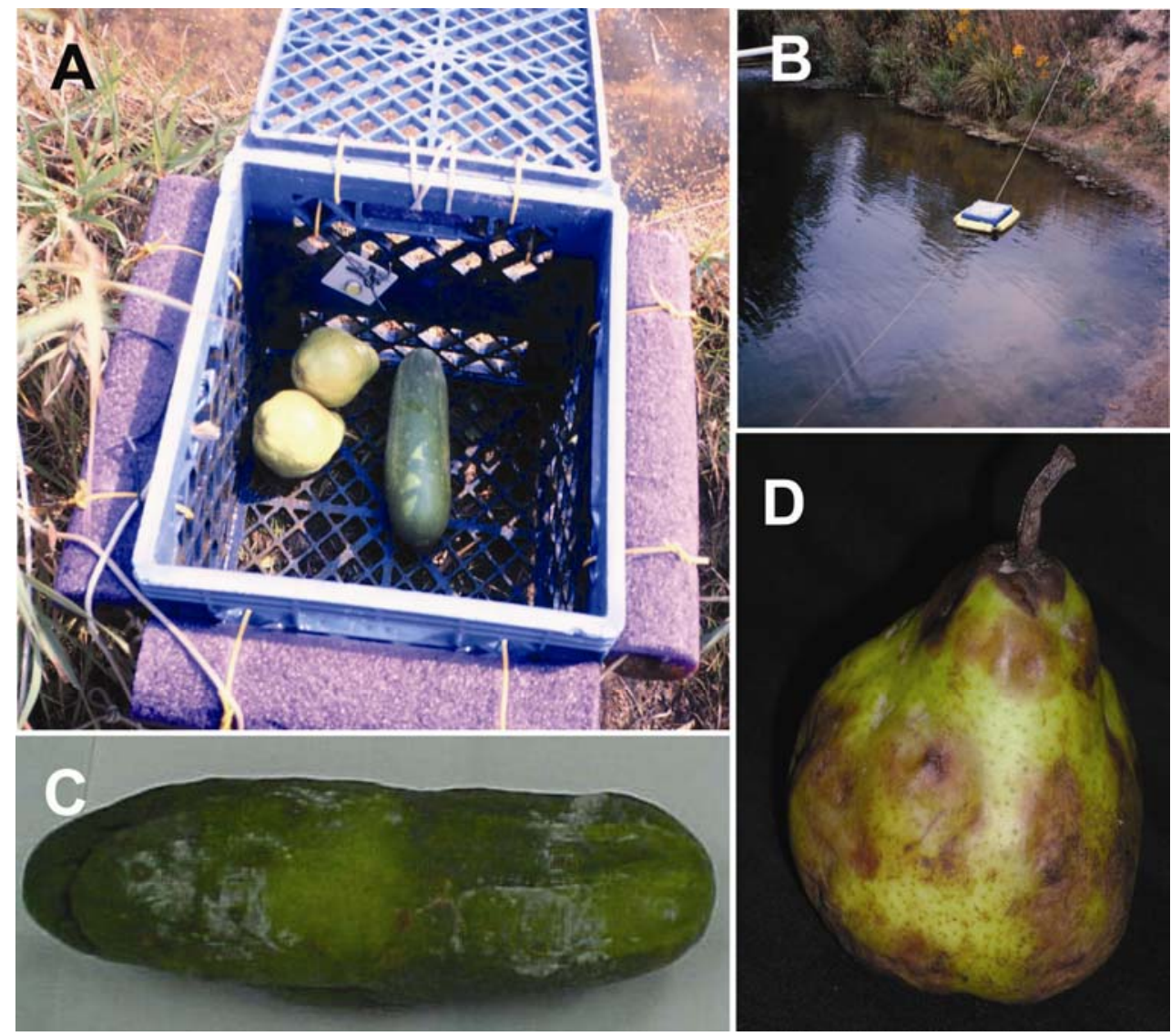

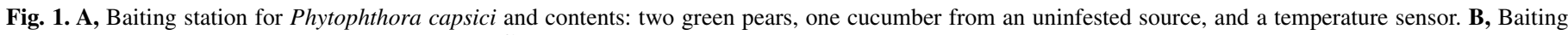
station deployed in a pond used for crop irrigation. $\mathbf{C}$ and $\mathbf{D}$, Cucumber and pear baits retrieved after 1 week in water monitoring site. 
nearby field were sampled (foliage, stems, tubers, and associated soil), but the pathogen was not detected. At SW2 to SW6 sites, when a nearby field was planted to cucumber, P. capsici disease symptoms were observed and included fruit with water-soaked lesions and pathogen sporulation (Table 1).

Ponds. $P$. capsici was detected in a naturally fed pond (NW1) and a pond fed by a deep well (NW3). In a second well-fed pond (NW2) with nearby field sites historically infested with $P$. capsici, the pathogen was not detected. Baiting in the naturally fed pond (NW1) was initiated late in the 2002 growing season in response to crop loss in an adjacent field due to $P$. capsici. The pathogen was detected immediately and throughout the remainder of the growing season. $P$. capsici was isolated from a nearby field of infected yellow squash in 2002 and from snap beans in 2003 (Table 1). No P. capsici was recovered from sampled carrots in 2004 (Table 1). Well-fed pond, NW3, had just a single baiting period with positive $P$. capsici detection.

Ditches. In 2004, monitoring was initiated in response to widespread and severe disease in a hand-harvested cucumber field in SE Michigan (Lenawee County). The detection of $P$. capsici at

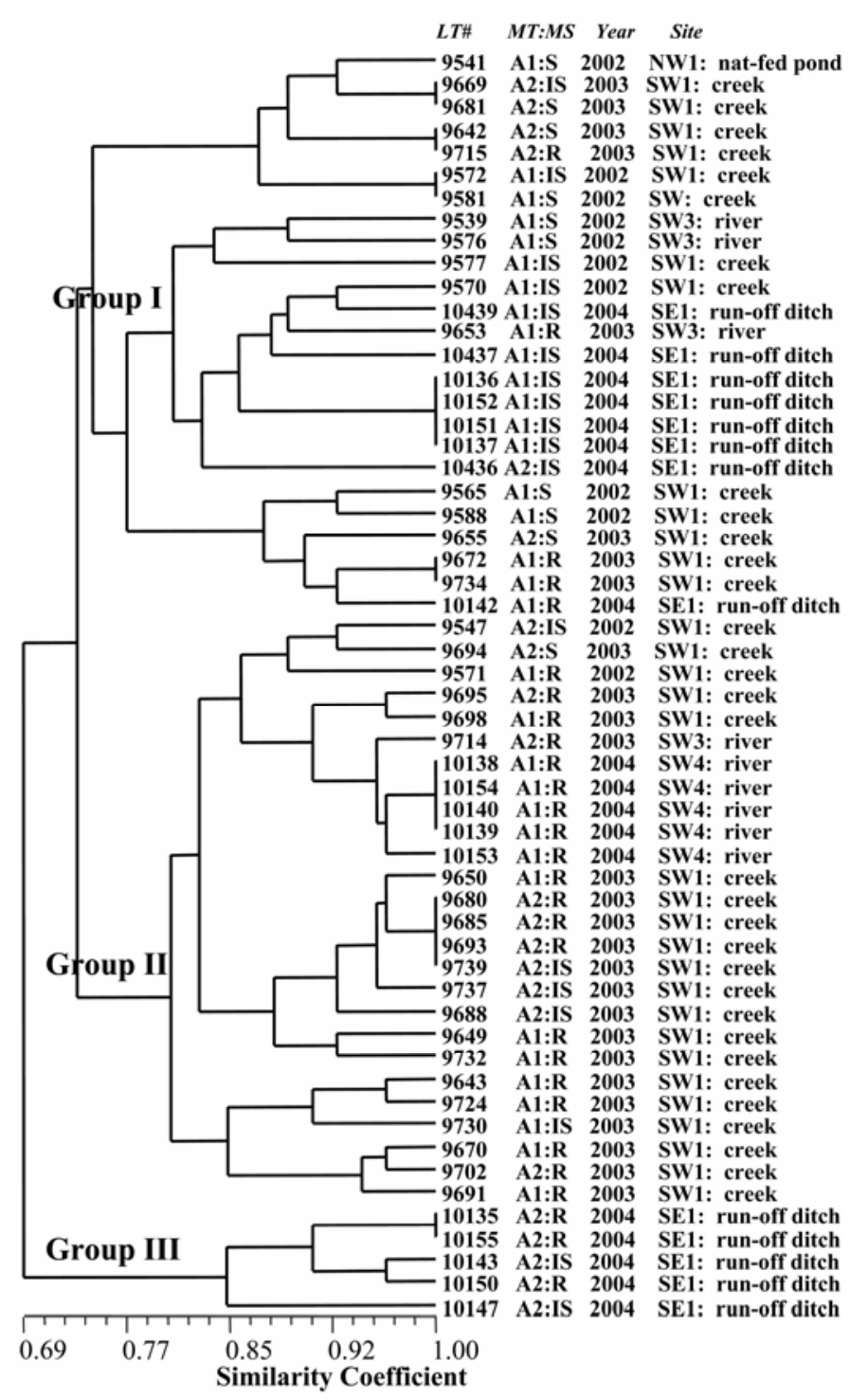

Fig. 2. Amplified fragment length polymorphism similarity tree of Phytophthora capsici isolated from Michigan surface water. Long-term numbers (LT\#) refer to culture numbers maintained in the laboratory of M. K. Hausbeck at Michigan State University. Mating types (MT) are either A1 or A2. Mefenoxam sensitivity (MS) characteristics are sensitive (S), intermediately sensitive (IS), and resistant (R). this site (SE1: run-off ditch) represents the first confirmation of this pathogen in water used for irrigation in SE Michigan. Despite our interest in continuing to monitor this site in 2005, the grower declined. The 2005 NW Michigan ditch site (NW4: culvert ditch) represented a culvert that received run-off from a number of fields, some with a known history of $P$. capsici infestation. The pathogen was detected immediately following baiting initiation and throughout the remainder of the growing season (Table 1).

MTs. For all monitoring sites where more than one $P$. capsici isolate was obtained, both A1 and A2 MTs were typically detected (Table 2). In several sites, the ratio of A1 to A2 was nearly 1:1 when totaled over the monitored years. At sites where the ratio was not close to a $1: 1$, the A1 MT occurred more frequently when examined across the isolate totals for a particular site (Table 2).

Mefenoxam sensitivity. Each year, river sites yielded $P$. capsici isolates of each of the mefenoxam sensitivity categories (sensitive $[\mathrm{S}]$, intermediately sensitive $[\mathrm{I}]$, and resistant $[\mathrm{R}]$ ) (Table 2). Approximately half of the $P$. capsici isolates from the river sites in 2002 were I with one quarter of the isolates R (Table 2). Most isolates from 2003 and 2004 were R (Table 2). In the last year of monitoring (2005), most ( $88 \%$ ) isolates were $\mathrm{S}$ (Table 2).

Nearly all $P$. capsici isolates collected from the NW Michigan region (Oceana County) during 2002 to 2005 were S (Table 2). In 2002, there was a single I isolate collected (Table 2). The culvert ditch monitored in 2005 yielded 14 P. capsici isolates, 13 of which were $\mathrm{S}$ to mefenoxam (Table 2). The majority of the $P$. capsici isolates from the run-off ditch monitored in 2004 in SE Michigan (Lenawee County) collected were I and approximately $30 \%$ were $\mathrm{R}$ (Table 2).

Water temperature. Water temperatures were significantly correlated to positive $P$. capsici detection from the monitoring sites from 2002 to 2005 when analyzed using a nonlinear quadratic polynomial regression $\left(R^{2}=0.9408\right)$ (Fig. 4). Most $(92 \%)$ of the baiting periods yielding $P$. capsici occurred during times when water temperatures were between 15 and $25^{\circ} \mathrm{C}$ (Table 3; Fig. 4). $P$. capsici was not identified from water sources when temperatures fell below $14^{\circ} \mathrm{C}$ or rose above $25^{\circ} \mathrm{C}$ (Table 3). Average water temperatures at the river monitoring sites during baiting periods with positive $P$. capsici detection were 17 to $19^{\circ} \mathrm{C}$. At the pond sites, average water temperatures during baiting periods with $P$. capsici infestation were 20 to $22^{\circ} \mathrm{C}$. The run-off and culvert ditch sites had average water temperatures of $21^{\circ} \mathrm{C}$ during baiting periods with positive $P$. capsici detection.

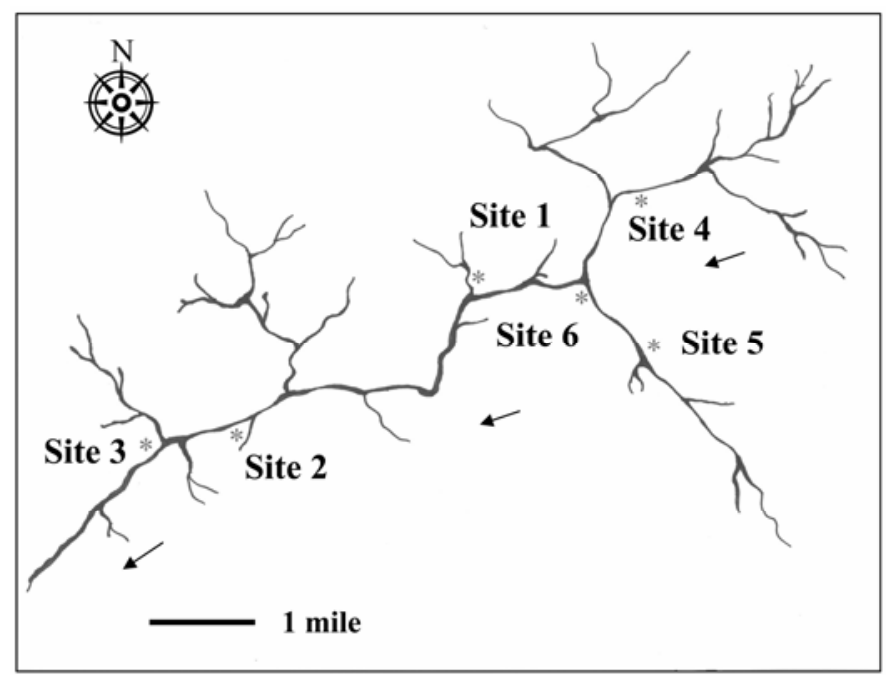

Fig. 3. Schematic of six sites along a river and creek system of southwest Michigan that were monitored for Phytophthora capsici infestation during the growing seasons of 2002 through 2005. Site 1 is a creek that flows into the river. Arrows indicate direction of water flow. 
Rainfall. For the river system, total rainfall accumulation was greatest in 2003 and 2004 (Fig. 5). During baiting periods when $P$. capsici was detected at river sites, rainfall accumulation averaged $<40 \mathrm{~mm}$ per week (Fig. 5). At the monitored pond sites in NW Michigan, little rainfall accumulation was recorded in 2002 and 2005, with the greatest accumulation in 2003 and 2004 (data not shown). Weekly rainfall accumulation was $<30 \mathrm{~mm}$ during baiting periods when $P$. capsici was detected at the Lenawee County ditch (data not shown). Little rainfall accumulation $(<10 \mathrm{~mm}$ weekly) was recorded at the Oceana County culvert ditch during baiting periods in 2005 (data not shown).

AFLP fingerprinting. Using the E-12/M-21 primer pair, a total of 27 reproducible AFLP markers were generated. Sixteen of the markers were polymorphic and the other 11 were present in all isolates (monomorphic). AFLP genotyping revealed that all of the monomorphic markers found in this data set are common in known $P$. capsici isolates supporting the morphological species identification of the isolates in this study. Genetic fingerprinting of $P$. capsici isolates collected from water monitoring sites from 2002 to 2004 did not indicate an association between similarity groups and specific locations, or years collected (Fig. 2). Three similarity groups (with $>80 \%$ similarity) were resolved from a cluster analysis of 56 isolates. Within the three similarity groups there are eight subgroups which contain isolates (2 to 4) with identical AFLP genotypes (Fig. 2). The eight groups were recovered from single locations during single years. Group I contained isolates from river, pond, and ditch sites from 2002 to 2004 (Fig. 2). The second group was comprised entirely of isolates from river sites 1, 3, and 4 from 2002 to 2004. The smallest of the similarity groups, group III, contained isolates from the Lenawee County ditch site from 2004 (Fig. 2).

\section{DISCUSSION}

Surface water used for irrigation was identified as a significant potential source of $P$. capsici dissemination that had previously not been recognized. It is likely that infested irrigation water has been a key means of dissemination of the pathogen in major vegetable producing regions in Michigan. Previously, pickling cucumbers planted at the Michigan State University Muck Soils
Research Farm in Laingsburg, Michigan, were inoculated with $P$. capsici by injecting zoospores and sporangia into the irrigation system. In just two irrigation events, cucumber fruit exhibited heavy $P$. capsici sporulation (K. H. Lamour and M. K. Hausbeck, unpublished data). P. capsici has persisted and susceptible crops planted in this plot become diseased without additional inoculation. Commercial cucumber growers have experienced significant losses even when using fields never planted to vegetables. Specifically, when a new cucumber farm was established on a virgin site in SW Michigan, there was a sudden and widespread disease outbreak. The source of irrigation water (SW2) was suspected as the means by which $P$. capsici was introduced. This research confirms that this was likely the case.

Although P. capsici was baited from surface water using pear and cucumber fruits, cucumber fruit were especially sensitive. Approximately $70 \%$ of all $P$. capsici isolates were collected from symptomatic cucumber. In addition to $P$. capsici, other oomycete

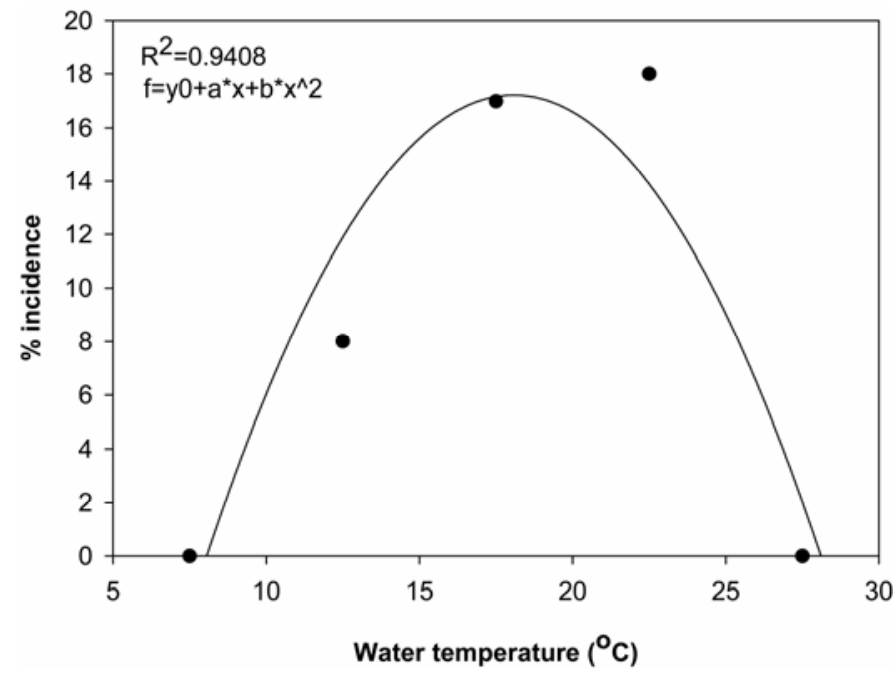

Fig. 4. Nonlinear, quadratic regression curve of average water temperature $\left({ }^{\circ} \mathrm{C}\right)$ during baiting periods from all sites and years $(2002$ to 2005$)$ and the percent incidence of Phytophthora capsici detection.

TABLE 2. Mating type (MT) and mefenoxam sensitivity characterization of Phytophthora capsici isolates from pear and cucumber bait tissue from Michigan water sources, 2002 to 2005

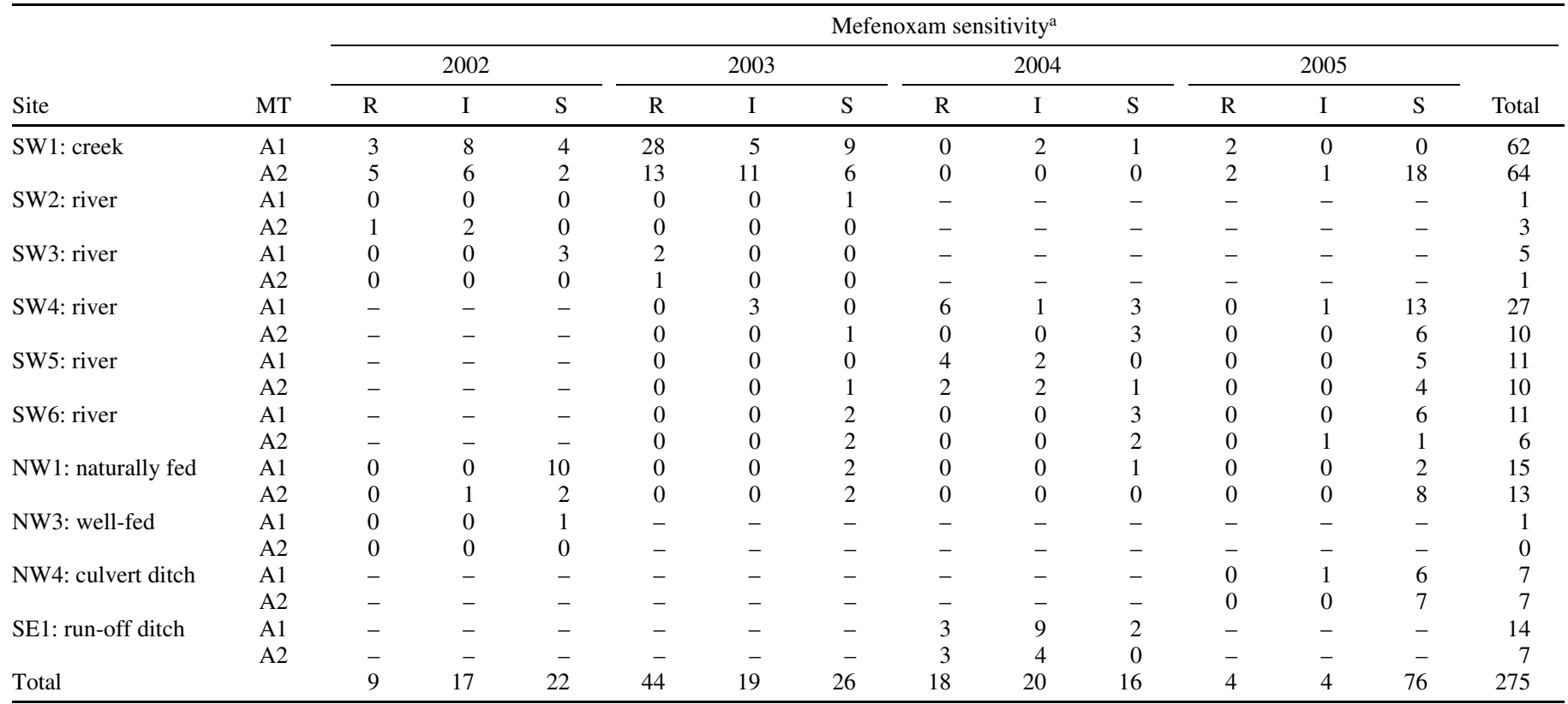

a Mefenoxam sensitivity rated as R (resistant), I (intermediately sensitive), and S (sensitive) to 100 ppm of mefenoxam. Mefenoxam formulation used was Ridomil Gold, Syngenta Crop Protection, Greensboro, NC. - Indicates that specific site was not monitored in that year of study. 
organisms were also isolated from both pear and cucumber fruits during the 4 years of monitoring. Based on morphological characteristics, Pythium spp. were identified, to genus only, each year and were prevalent during the early (April and May) and late (September and October) portions of the growing season (data not shown). P. citricola was identified to species by sequence analysis of the internal transcribed spacer 1 (ITS1) and ITS2 spacer regions (data not shown). Other Phytophthora spp. were identified to genus based on morphological characteristics.

Water temperature exhibited some influence on the frequency of $P$. capsici detection. In our study, regression analysis determined that water temperatures were correlated with $P$. capsici incidence on pear and cucumber baits $\left(R^{2}=0.9408\right)$. There appeared to be a lower temperature threshold $\left(14^{\circ} \mathrm{C}\right)$ at which $P$. capsici was not detected. When lupines were used to bait for Phytophthora spp. in cranberry irrigation reservoirs in New Jersey, a significant positive correlation was observed between water temperature and detection of $P$. cinnamomi; a negative relationship was observed for temperature and P. megasperma (34).

TABLE 3. Average water temperature $\left({ }^{\circ} \mathrm{C}\right)$ during baiting periods from all sites and years (2002 to 2005) and the number of baiting periods with positive detection of Phytophthora capsici

\begin{tabular}{lccc}
\hline $\begin{array}{l}\text { Temperature } \\
\text { during baiting }\left({ }^{\circ} \mathrm{C}\right)\end{array}$ & $\begin{array}{c}\text { Total no. of } \\
\text { baiting periods }\end{array}$ & $\begin{array}{c}\text { No. of baiting periods } \\
\text { with } \text { P. capsici }\end{array}$ & $\begin{array}{c}\text { Incidence } \\
(\%)\end{array}$ \\
\hline $5-10$ & 24 & 0 & 0 \\
$10-15$ & 114 & 6 & 8 \\
$15-20$ & 277 & 47 & 17 \\
$20-25$ & 120 & 21 & 18 \\
$25-30$ & 8 & 0 & 0 \\
\hline
\end{tabular}

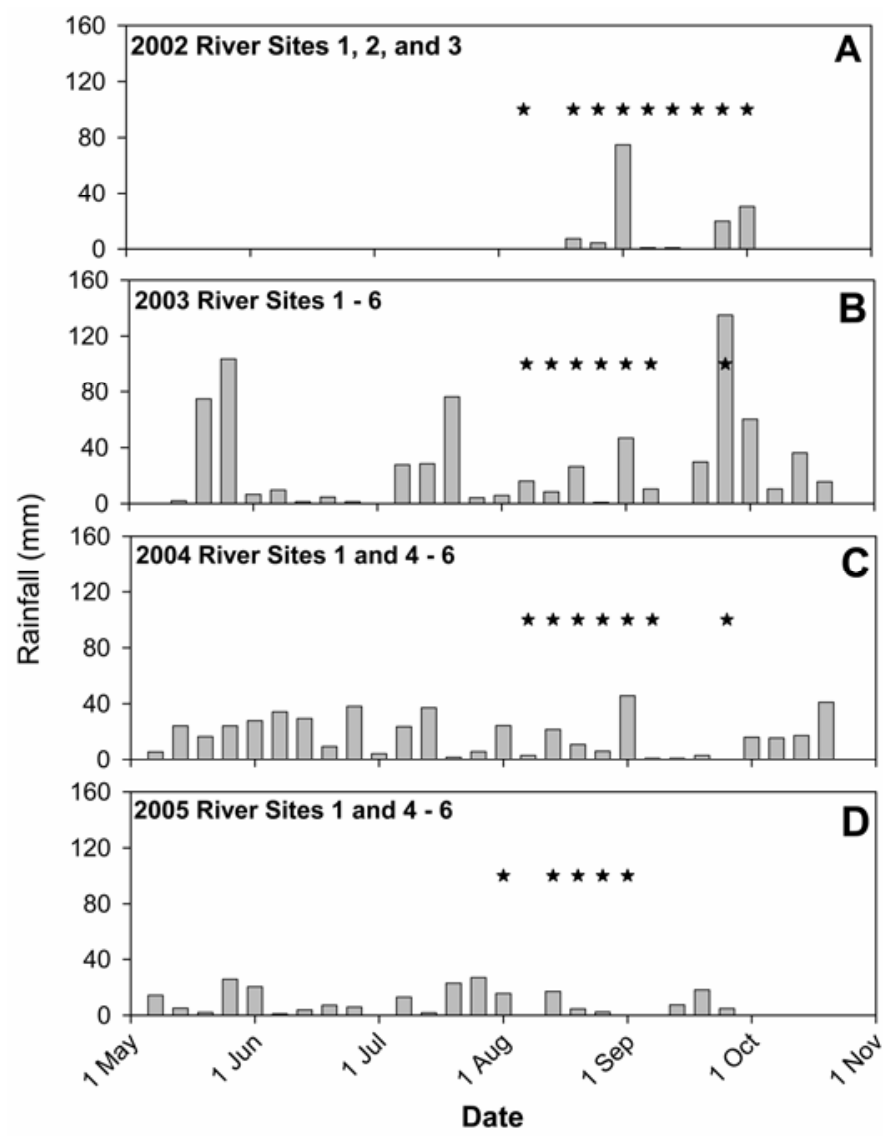

Fig. 5. Rainfall (weekly totals) and Phytophthora capsici detection data for SW river monitoring sites in Allegan County, Michigan, in A, 2002, B, 2003, C, 2004, and D, 2005. Gray vertical bars indicate rainfall (mm). Stars indicate positive $P$. capsici detection.
P. palmivora and $P$. citrophthora have been shown to remain motile in water at an optimal temperature of 17 and $12.5^{\circ} \mathrm{C}$, respecttively (7). The length of time zoospores can continue to swim and remain viable may be impacted by water temperature $(7,8)$. Further laboratory studies may elucidate the relationship between water temperature and $P$. capsici zoospore activity. In Michigan, low water temperature typically occurs at a time when crops may not be established (early spring) or have been removed (early fall).

Frequency of $P$. capsici detection was greatest at river and ditch sites and rare at pond sites fed by deep wells. Although river water can have many potential points of infestation and is an unreliable source for clean irrigation water, ponds may also harbor $P$. capsici. The naturally fed pond, NW1, yielded $P$. capsici in each of the 4 years monitored despite the planting of non-host crops in the nearby field in two of these years. One of the two well-fed ponds (NW3) yielded just one $P$. capsici isolate during our monitoring. Ponds fed by deep wells are a safer option for growers than using surface water for irrigation, provided that runoff from nearby fields does not enter the holding pond. The ditches in our study received direct run-off of water from numerous infested fields and yielded $P$. capsici for nearly every period monitored. Both ditch sites fed into water retention/pumping ponds used for irrigation.

Rain and/or irrigation events likely prompt run-off from fields with $P$. capsici-infected crops into ditches, rivers, and creeks. However, precipitation data do not clearly indicate pathogen detection following significant rainfall. Grower irrigation data were not collected and may have impacted surface water infestation. Michigan cucurbit growers attempt to provide an average of $1 \mathrm{in}$. of water to their crops per week during the summer growing months. Monitoring water during the host crop-growing season indicated that irrigation water was often infested when the need to irrigate crops was highest, typically in late July and August, increasing the risk for pathogen dissemination.

$P$. capsici was most frequently detected in water at monitoring sites during years when crown and fruit rot was observed in a nearby field. However, $P$. capsici was consistently detected in irrigation sources even after 1 to 3 years without a host crop growing nearby. $P$. capsici can persist within the environment outside of host tissue $(9,23,37)$. In Michigan, molecular techniques have confirmed that $P$. capsici oospores can survive dormantly in soil for 3 years (23). Weed species have been identified as alternative hosts for $P$. capsici under Florida field conditions $(9,35)$. P capsici may be a weak pathogen of weed species or may simply colonize weed root systems (9). In addition, rotational crops may not be serving to limit the overall soil population of the pathogen. Snap beans were increasingly grown in rotation to vegetable crops in Michigan, prior to 2003. Unfortunately, snap beans have since been determined to be susceptible to $P$. capsici under field conditions in Michigan and other vegetable-producing regions of the United States (11).

The consistent presence of the pathogen in moving surface water without a nearby infected host crop may indicate a long range of movement of $P$. capsici. In a study of the movement of a Phytophthora sp. (interspecific hybrid of P. cambivora and an unknown Phytophthora sp. related to P. fragariae) on alder in Bavaria, it was determined that once the pathogen was introduced into a river system upstream, it infected alders downstream (17). In addition, area nurseries that had high incidence of infected alder seedlings were found to be using water from infested river courses for irrigation (17). Due to the proximity of the Michigan river system to susceptible crop production, there are numerous potential sources of $P$. capsici infestation. Drainage tiling may also be responsible for the movement of infested water. Subsurface drainage tiling, for removal of excess field water, occurs through a network of perforated plastic tubes installed below the soil surface. Water from the tiles eventually drains into ditches, 
retention ponds, rivers, creeks, and lakes. It is difficult to estimate how far P. capsici can move via water based on the data presented here because we did not detect identical AFLP genotypes from multiple locations. The identical genotypes (similarity subgroups) recovered from individual sites likely represented the dispersal of asexual sporangia and zoospores, as $P$. capsici sporulates heavily on host crops.

Isolates of $P$. capsici resistant to mefenoxam may be disseminated by irrigation. The extensive use of phenylamide fungicides for disease management can render $P$. capsici field populations resistant (19-21). Growers in SW Michigan have a long history of phenylamide fungicide use (mefenoxam and/or metalaxyl) compared with growers in NW Michigan. Mefenoxam has been relied upon only in recent years to manage vegetable diseases in the SE region. Characterization of populations of P. capsici collected from SW Michigan from 1997 to 2001 indicated a high incidence of mefenoxam insensitivity (21), whereas isolates from NW Michigan were sensitive to the fungicide (20).

In the first monitoring year (2002), most isolates obtained from the river sites in SW Michigan were intermediately sensitive to the fungicide mefenoxam; in the subsequent 2 years, approximately half of the isolates were completely resistant. However, in 2005 , all but $10 \%$ of the isolates were sensitive to mefenoxam. From 2003 to 2005, SW Michigan vegetable growers either avoided or limited their use of mefenoxam because of its ineffectiveness in disease management due to fungicide resistance. Previously, a $P$. capsici field population from SW Michigan did not revert from mefenoxam resistant to sensitive during a 2-year rotation to non-host crops (21). The isolates collected in 2005 from SW1 may have been introduced from a source different from the nearby field or the number of sensitive isolates may be elevated due to the influx of a single asexual genotype. It has been noted with another oomycete pathogen (Pythium aphanidermatum) that metalaxyl-resistant isolates declined in number after metalaxyl use was eliminated for at least 3 years. Although the sensitive isolates became more prevalent, they were not in numbers large enough to allow the use of metalaxyl for disease management (45).

$P$. capsici does not appear to be overwintering (asexually) in the water sources. Fingerprints were not monomorphic across years at individual monitoring sites and the pathogen was never detected in the spring or early summer. In addition, the pathogen was never detected prior to mid-July or after late September, despite water monitoring efforts which began in April and ended in late October for most sites in this study. Continued irrigation baiting in 2006 has yielded $P$. capsici from cucumber fruit as early as 30 June (M. K. Hausbeck, unpublished data). There was no association between $P$. capsici similarity groups and specific locations or years. This may be due to the relatively small sample sets analyzed or could be due to long-distance movement of the pathogen via the water sources. The genotypic diversity among the isolates analyzed underscores the importance of sexual recombination in the life cycle of $P$. capsici and also shows that these water sources provide an important, genetically diverse, reservoir of propagules during key vegetable production months. Use of surface water for irrigation of $P$. capsici-susceptible crops should be avoided to prevent further spread of the pathogen.

\section{ACKNOWLEDGMENTS}

This study was funded by Michigan Specialty Crop Block Grant for Pickling Cucumbers: Increase Marketability of Cucumbers for Pickling by Decreasing Fruit Rot Caused by Phytophthora and Pythium and Project GREEEN (a cooperative effort by plant-based commodities and businesses with Michigan State University Extension, the Michigan Agricultural Experiment Station, and the Michigan Department of Agriculture). We thank J. Woodworth and K. Cervantes of Michigan State University for technical support, and the Michigan grower cooperators who allowed us access to surface water sources and nearby fields.

\section{LITERATURE CITED}

1. Alconero, R., and Santiago, A. 1972. Characteristics of asexual sporulation in Phytophthora palmivora and Phytophthora parasitica nicotianae. Phytopathology 62:993-997.

2. Babadoost, M., and Islam, S. Z. 2001. Evaluation of fungicides for control of Phytophthora blight of processing pumpkin, 2000. Online Publication. Fungic. Nematic. Tests 56:V65.

3. Bernhardt, E. A., and Grogan, R. G. 1982. Effect of soil matric potential on the formation and indirect germination of sporangia of Phytophthora parasitica, Phytophthora capsici, and Phytophthora cryptogea rots of tomatoes, Lycopersicon esculentum. Phytopathology 72:507-511.

4. Bush, E. A., Hong, C., and Stromberg, E. L. 2003. Fluctuations of Phytophthora and Pythium spp. in components of a recycling irrigation system. Plant Dis. 87:1500-1506.

5. Crossan, D. F., Haasis, F. A., and Ellis, D. E. 1954. Phytophthora blight of summer squash. Plant Dis. Rep. 38:557-559.

6. Davidson, C. R., Carroll, R. B., Evans, T. A., Mulrooney, R. P., and Kim, S. H. 2002. First report of Phytophthora capsici infecting lima bean (Phaseolus lunatus) in the Mid-Atlantic Region. Plant Dis. 86:1049.

7. Erwin, D. C., Bartnicki-Garcia, S., and Tsao, P. H. 1983. Pages 60-276 in: Phytophthora: Its Biology, Taxonomy, Ecology, and Pathology. The American Phytopathological Society, St. Paul, MN.

8. Erwin, D. C., and Ribeiro, O. K. 1996. Pages 50-266 in: Phytophthora Diseases Worldwide. The American Phytopathological Society, St. Paul, MN.

9. French-Monar, R. D., Jones, J. B., and Roberts, P. D. 2006. Characterization of Phytophthora capsici associated with roots of weeds on Florida vegetable farms. Plant Dis. 90:345-350.

10. Gevens, A. J., and Hausbeck, M. K. 2004. Characterization and distribution of Phytophthora capsici from irrigation water near Michigan cucurbit fields: A first report of Phytophthora capsici in irrigation water in Michigan. (Abstr.) Phytopathology 94(suppl.):S157.

11. Gevens, A. J., and Hausbeck, M. K. 2004. Phytophthora capsici isolated from snap bean is pathogenic to cucumber fruit and soybean. (Abstr.) Phytopathology 95(suppl.):S162.

12. Gevens, A. J., Lamour, K. H., and Hausbeck, M. K. 2005. Screening cucumber germplasm for resistance to Phytophthora capsici using a detached fruit method. (Abstr.) Phytopathology 95(suppl.):S34.

13. Habera, L., Smith, N., Donahoo, R., and Lamour, K. 2004. Use of a single primer to fluorescently label selective amplified fragment length polymorphism reactions. BioTechniques 37:902-904.

14. Hausbeck, M. K., and Lamour, K. H. 2004. Phytophthora capsici on vegetable crops: Research progress and management challenges. Plant Dis. 88:1292-1303.

15. Hong, C., Richardson, R. P., and Kong, P. 2002. Comparison of membrane filters as a tool for isolating Pythiaceous species from irrigation water. Phytopathology 92:610-616.

16. Hwang, B. K., and Kim, C. H. 1995. Phytophthora blight of pepper and its control in Korea. Plant Dis. 79:221-227.

17. Jung, T., and Blaschke, M. 2004. Phytophthora root and collar rot of alders in Bavaria: Distribution, modes of spread and possible management strategies. Plant Pathol. 53:197-208.

18. Ko, W. 1988. Hormonal heterothallism and homothallism in Phytophthora. Annu. Rev. Phytopathol. 26:57-73.

19. Lamour, K. H., and Hausbeck, M. K. 2000. Mefenoxam insensitivity and the sexual stage of Phytophthora capsici in Michigan cucurbit fields. Phytopathology 90:396-400.

20. Lamour, K. H., and Hausbeck, M. K. 2001. Investigating the spatiotemporal genetic structure of Phytophthora capsici in Michigan. Phytopathology 91:973-980.

21. Lamour, K. H., and Hausbeck, M. K. 2001. The dynamics of mefenoxam insensitivity in a recombining population of Phytophthora capsici characterized with amplified fragment length polymorphism markers. Phytopathology 91:553-557.

22. Lamour, K. H., and Hausbeck, M. K. 2003. Susceptibility of mefenoxamtreated cucurbits to isolates of Phytophthora capsici sensitive and insensitive to mefenoxam. Plant Dis. 87:920-922.

23. Lamour, K. H., and Hausbeck, M. K. 2003. Effect of crop rotation on the survival of Phytophthora capsici in Michigan. Plant Dis. 87:841-845.

24. Larkin, R. P., Gumpertz, M. L., and Ristaino, J. B. 1995. Geostatistical analysis of Phytophthora epidemic development in commercial bell pepper fields. Phytopathology 85:191-203.

25. Louws, F. J., Lancaster, M. E., Holmes, G. J., and Driver, J. G. 2000. Evaluation of fungicides and host resistance for control of Phytophthora crown rot of pepper, 1999. Fungic. Nematic. Tests 55:188.

26. Matheron, M. E., and Porchas, M. 2002. Suppression of Phytophthora root and crown rot on pepper plants treated with acibenzolar- $S$-methyl. Plant Dis. 86:292-297.

27. McGovern, R. J., Davis, T. A., Myers, D. S., and Seijo, T. E. 2003. 
Evaluation of fungicides for control of diseases of tropical pumpkin, 2001. Online publication. Fungic. Nematic. Tests 58:V124.

28. McGrath, M. T. 2004. Evaluation of fungicides for managing Phytophthora blight of squash, 2003. Online publication. Fungic. Nematic. Tests 59:V054.

29. McIntosh, D. L. 1964. Phytophthora spp. in soils of the Okanagan and Similkameen Valleys of British Columbia. Can. J. Bot. 42:1411-1415.

30. Miller, S. A., Bhat, R. G., and Schmitthenner, A. F. 1994. Detection of Phytophthora capsici in pepper and cucurbit crops in Ohio with two commercial immunoassay kits. Plant Dis. 78:1042-1046.

31. Mitchell, D. J., and Kannwischer-Mitchell, M. E. 1992. Phytophthora. Pages 31-38 in: Methods for Research on Soilborne Phytopathogenic Fungi. L. L. Singleton, J. D. Mihail, and C. M. Rush, eds. The American Phytopathological Society, St. Paul, MN.

32. Neher, D., and Duniway, J. M. 1992. Dispersal of Phytophthora parasitica in tomato field by furrow irrigation. Plant Dis. 76:582-586.

33. Noon, J. P., and Hickman, C. J. 1974. Oospore production by a single isolate of Phytophthora capsici in the presence of chloroneb. Can. J. Bot. 52:1591-1595.

34. Oudemans, P. V. 1999. Phytophthora species associated with cranberry root rot and surface irrigation water in New Jersey. Plant Dis. 83:251-258.

35. Ploetz, R. C., Heine, G., Haynes, J., and Watson, M. 2002. An investigation of biological attributes that may contribute to the importance of Phytophthora capsici as a vegetable pathogen in Florida. Ann. Appl. Biol. 140:61-67.

36. Ristaino, J. B., and Johnston, S. A. 1999. Ecologically based approaches to management of Phytophthora blight on bell pepper. Plant Dis. 83:10801089.

37. Roberts, P. D., French-Monar, R. D., Hoffine, M. S., Seijo, T. E., and McGovern, R. J. 2005. Survival and recovery of Phytophthora capsici and oomycetes in tailwater and soil from vegetable fields in Florida. Ann. Appl. Biol. 146:351-359.

38. Schlub, R. L. 1983. Epidemiology of Phytophthora capsici on bell pepper. J. Agric. Sci. 100:7-11.

39. Schmitthenner, A. F., and Bhat, R. G. 1994. Useful methods for studying Phytophthora in the laboratory. OARDC, Wooster, $\mathrm{OH}$

40. Seebold, K. W., and Horten, T. B. 2003. Evaluation of fungicides for control of Phytophthora crown and fruit rot of summer squash, 2002. Online publication. Fungic. Nematic. Tests 58:V098.

41. Stevenson, W. R., James, R. V., and Rand, R. E. 2000. Evaluation of selected fungicides to control Phytophthora blight and fruit rot of cucumber. Fungic. Nematic. Tests 55:163.

42. Stevenson, W. R., James, R. V., and Rand, R. E. 2001. Evaluation of selected fungicides to control Phytophthora blight and fruit rot of cucumber. Online publication. Fungic. Nematic. Tests 56:V16.

43. Tucker, C. M. 1931. Taxonomy of the Genus Phytophthora DeBary. University of Missouri, Columbia.

44. Uchida, J. Y., and Aragaki, M. 1980. Chemical stimulation of oospore formation in Phytophthora capsici. Mycologia 72:1103-1108.

45. Vargas, J. M., Jr. 2004. Fungicides. Pages 125-164 in: Management of Turfgrass Diseases, 3rd ed. Wiley Publishing, John Wiley \& Sons, Hoboken, NJ.

46. Vos, P., Hogers, R., Blecker, M., Reijans, M., van der Lee, T., Hornes, M., Frijters, A., and Pot, J. 1995. AFLP: A new technique for DNA fingerprinting. Nucleic Acids Res. 23:4407-4414.

47. Waldenmaier, C. M. 2004. Evaluation of fungicides for control of pumpkin diseases, 2003. Online publication. Fungic. Nematic. Tests 59:V064.

48. Waterhouse, G. 1963. Key to the species of Phytophthora de Bary. Mycological Papers, No. 92, Commonwealth Mycological Society, Kew, England.

49. Yamak, F., Peever, T. L., Grove, G. G., and Boal, R. J. 2002. Occurrence and identification of Phytophthora spp. pathogenic to pear fruit in irrigation water in the Wenatchee River valley of Washington State. Phytopathology 92:1210-1217. 